\title{
LEADERSHIP STYLES AND CONFLICT MANAGEMENT STRATEGIES OF HEAD NURSES AT MANSOURA UNIVERSITY HOSPITAL
}

\author{
1 Amira A Ibrahim, ${ }^{2}$ Ahlam M El-Shaer, ${ }^{3}$ Neamat M El-Sayed
}

${ }^{1,2}$ Nursing Administration, faculty of Nursing,Mansoura University, ${ }^{3}$ Damanhour University e-mail dr_ami_2011@yahoo.com

\begin{abstract}
:
Introduction: Nowadays, hospitals are operating in a turbulent environment where organizations and institutions are searching for measures that will allow them to improve their performance and competitiveness. The achievement and stability of an organization depends on the ability of conflict recognition and the competency of leaders in managing conflict at workplaces Aim: Investigate relationship between leadership styles and conflict management strategies of head nurses at Mansoura University Hospital. Design: descriptive design. Setting: Mansoura University hospital. Subjects and methods: The total study sample composed of 90 head nurses. Data was collected by using Multi factor Leadership Questionnaire (MLQ) and Rahim Organizational Conflict Inventory -II (Rahim, 2010, 1983) .Results: revealed that there was statistically significant correlation between integrating, obliging and compromising conflict strategies practice with three leadership styles $(\mathrm{P}<0.05)$. There was diversity of using three leadership styles among head nurses sample based on different situations. The highest degree of opinion score related to practice of transformational leadership followed by laissez faire .The integrating strategy has the highly degree of practice followed by obliging. Recommendation: Encourage open discussion and effective communication policy, implementing educational program on conflict management strategies and leadership styles. Periodically check up for staff needs and problems and conduct an organizational conflict assessment. Good understanding of the strengths and weaknesses of the nursing team members in order to improve relations and manage conflict successfully. Promote critical thinking and the scientific method to solve problems by providing opportunities for staff nurses to express their opinion and participation in the development of new ideas and non-traditional solutions to improve performance.
\end{abstract}

Key Words: leadership Styles, Conflict Management Strategies, Head Nurses.

\section{Introduction:}

The dynamic and uncertain nature of health care environment requires nursing managers to be competent leaders in order to respond to clients' needs. The role and influence of leadership are becoming increasingly important in today's complex and continually changing health care organizations ${ }^{(1)}$. Leader must be able to employ various leadership skills, such as effective direction, meeting current health care challenges and managing conflict to maintain a smoothly functioning workplace and provide optimal care to patients $^{(2)}$.

Leadership style defined as the broad, characteristic way in which a leader interacts with others in various situations. There are different leadership styles as transformational, transactional and Laissez-faire leadership style ${ }^{(3)}$.

Transformational leadership includes five components which are charisma, idealized influence inspirational, intellectual stimulation sindividual consideration ${ }^{(4) \text {. }}$ 
Transactional leadership is defined by different elements. Contingent reward, management-by-exception (active, passive) finally, the absence or avoidance of any leadership behaviors is termed laissez-faire leadership ${ }^{(5)}$.

Leadership style and choice of conflict management strategies strongly influence outcomes of a conflict. The ability to creatively manage conflict in the organization is becoming a standard requirement for effective leader (4). Conflict is the disagreement between at least two persons or groups on specific issues, or it is a processing which one party perceives that its interests are being opposed or negatively affected by another party $^{(6)}$. It classified to intrapersonal, interpersonal, intra-group, and intergroup $^{(7) \text {. }}$

Conflict management strategy is a multidimensional concept that consists of five styles of conflict management including integrating, obliging , dominating, avoidant, and compromising (8).

When leaders handle conflict effectively, problem solving increases, interpersonal relationships become stronger, and stress surrounding the conflict decreases ${ }^{(9)}$.

\section{Aim of study:}

The aim of the current study is to assess the relationship between leadership styles and conflict management strategies of head nurses at Mansoura University Hospital.

\section{Subjects and methods:}

-Study Design: - A descriptive design was used to carry out this study.

-Setting:-

The study will be carried out in Main Mansoura University Hospital, which has a bed capacity 1800 beds.

- Subjects:-

The study sample included all head nurses available at the time of data collection in the previously mentioned settings. Their total numbers was 90 head nurses.

-Tools of data collection:-

The first tool: Multi factor Leadership Questionnaire (MLQ) developed by Bass \& Avolio 1995, which includes three parts. Part one includes personal characteristics. Part two describes three leadership styles namely transformational, transactional and laissez faire leadership styles. Part three includes leadership outcomes namely extra effort, satisfaction and effectiveness.

The Second tool: Rahim Organizational Conflict Inventory -II (Rahim, 2010, 1983). Includes two parts, Part one: that describes nature and reason of the conflicts. Part two: that describes Conflict management strategies.

Scoring system: MLQ measured on a five point Likert scale ranged from $1=$ not at all to $5=$ always.

Rahim Organizational Conflict Inventory -II measured on 5-point Likert scale ranged from 1 strongly disagree to 5 strongly agree.

\section{Statistical Analysis}

Data entry and statistical analysis were done using Statistical Package for Social Science (SPSS), version 16.0. Data were presented using descriptive statistics in the form of frequencies and percentages for qualitative variables, and means and standard deviations for quantitative variables. Chi- Square $(\chi 2)$ test was used to test association between variables. F value of ANOVA test was calculated. Correlation coefficient(r) test was used to test the closeness of association between two variables. Statistical significance was considered at $\mathrm{p}$-value $<0.05$ while, $\mathrm{p}$-value of $<0.001$ indicates a high significant result.

\section{Results:}

Table (1): Demographic characteristics of the head nurses at Mansoura University Hospital. This table shows that more than half of head nurses $57.8 \%$ were below the age 31 years old, while small percentage 
$6.7 \%$ were in age group $>40$ years old. Regarding educational qualification, most of them $83.3 \%$ having a bachelor's degree, while $4.4 \%$ of head nurses having master degree. Concerning marital status, high percentage of them $77.8 \%$ were married, while small percentage $2.2 \%$ are widow and divorced. The table also illustrate that approximately less than half of studied sample $44.4 \%$ having professional experience less than 6 years, and $31.1 \%$ having $>10$ years of experience.

Table (2): Mean scores of leadership styles as perceived by head nurses at Mansoura University Hospital . Contingent reward as a component of transactional style had the highest mean score $\quad($ mean $=15.42 \pm 3.03) \quad$ while, management by exception (active) had the lowest score (mean $=14.73 \pm 2.80$ ). Regarding to transformational style, the idealized influence achieved the highest score $($ mean $=30.51 \pm 5.11)$. Individualized consideration achieved the lowest score (mean $=14.79 \pm 2.70$ ) significantly lower than three components. As laissez faire leadership style had $15.73 \pm 3.05$ mean score, while the total mean score was 136.15 \pm 19.73 .

Table (3): Mean scores of conflict management strategies practice as perceived by head nurses at Mansoura University Hospital .

According to the table, integrating strategy has the highly degree of opinion scores $(85.6 \%)$ of head nurses with mean score $(28.83 \pm 3.68)$ followed by obliging and dominating $(73.3 \%, \quad 62.2 \%)$ respectively with mean score $(23.83 \pm 2.88$ $\& 17.72 \pm 5.29$ ) respectively, while avoiding strategy has the lowest degree of opinion scores $(21.1 \%)$ with mean score
(18.13 \pm 5.57$)$ followed by dominating and compromising $\quad(14.4 \%$ and $6.7 \%)$ respectively.

Table (4): Relation between practice of transactional leadership style and conflict management strategies as perceived by head nurses at Mansoura university hospital. The table show that statistically significances relationship between integrating strategy practice and practice of transactional leadership style $(p=$ $0.002 *)$.

Table (5): Relation between practice of transformational leadership style and conflict management strategies as perceived by head nurses at Mansoura university hospital. From the table, statistically significances relationship between integrating, obliging practice and practice of transformational leadership style $(p=0.002 *, 0.001 *)$ respectively.

Table (6): Relationship between practices of laissez faire leadership styles and conflict management strategies as perceived by head nurses at Mansoura university hospital.

The table shows that statistically significances relationship between integrating, obliging and avoiding practice and practice of laissez faire leadership style $\left(p=0.001 *, \quad 0.001 * \& \quad 0.005^{*}\right)$ respectively.

Table (7): Correlation between leadership styles and their practice of conflict management strategies as perceived by head nurses at Mansoura university hospital.

The result shows statistically significant correlation between integrating, obliging and compromising conflict strategies practice with three leadership styles 
Amira A Ibrahim et. al.

\begin{tabular}{|c|c|c|}
\hline \multirow[t]{2}{*}{ Variables } & \multicolumn{2}{|c|}{$\begin{array}{l}\text { The head nurses } \\
(n=90)\end{array}$} \\
\hline & $\mathbf{N}$ & $\%$ \\
\hline \multicolumn{3}{|l|}{-Age (years): } \\
\hline $20-$ & 52 & 57.8 \\
\hline $31-$ & 32 & 35.6 \\
\hline$>40$ & 6 & 6.7 \\
\hline Range & \multicolumn{2}{|c|}{$20-46$} \\
\hline Mean \pm SD & \multicolumn{2}{|c|}{$27.87 \pm 6.19$} \\
\hline \multicolumn{3}{|l|}{-Educational qualification: } \\
\hline Nursing diploma & 6 & 6.7 \\
\hline Bachelor degree & 75 & 83.3 \\
\hline Bsc degree +diploma & 5 & 5.6 \\
\hline Master & 4 & 4.4 \\
\hline \multicolumn{3}{|l|}{-Marital status: } \\
\hline Single & 18 & 20.0 \\
\hline Married & 70 & 77.8 \\
\hline Divorced & 1 & 1.1 \\
\hline Widow & 1 & 1.1 \\
\hline \multicolumn{3}{|l|}{-Experience years: } \\
\hline $1-$ & 40 & 44.4 \\
\hline 6- & 22 & 24.4 \\
\hline$>10$ & 28 & 31.1 \\
\hline Range & \multirow{2}{*}{\multicolumn{2}{|c|}{$\begin{array}{c}1-16 \\
7.20 \pm 3.88\end{array}$}} \\
\hline Mean \pm SD & & \\
\hline
\end{tabular}

Table (2): Mean scores of leadership styles as perceived by head nurses at Mansoura University Hospital .

\begin{tabular}{|c|c|c|c|}
\hline \multirow{2}{*}{ Leadership styles } & \multirow{2}{*}{$\begin{array}{c}\text { Upper } \\
\text { \&lower limit }\end{array}$} & \multicolumn{2}{|c|}{ Head nurses $(n=90)$} \\
\hline & & Range & Mean \pm SD \\
\hline $\begin{array}{l}\text {-Transactional leadership style: } \\
\text { a-Contingent reward } \\
\text { b-Management by exception(active) } \\
\text { c-Management by exception (passive) }\end{array}$ & $\begin{array}{l}(4-20) \\
(4-20) \\
(4-20)\end{array}$ & $\begin{array}{l}5-20 \\
8-20 \\
4-20\end{array}$ & $\begin{array}{l}15.42 \pm 3.03 \\
14.73 \pm 2.80 \\
15.08 \pm 3.04\end{array}$ \\
\hline Total & $(12-60)$ & $17-60$ & $45.23 \pm 7.52$ \\
\hline $\begin{array}{l}\text {-Transformational leadership style: } \\
\text { a-Idealized influence } \\
\text { b-Inspirational motivation } \\
\text { c-Intellectual stimulation } \\
\text { d-individualized consideration }\end{array}$ & $\begin{array}{l}(8-40) \\
(4-20) \\
(4-20) \\
(4-20)\end{array}$ & $\begin{array}{l}12-40 \\
8-20 \\
6-20 \\
6-20\end{array}$ & $\begin{array}{l}30.51 \pm 5.11 \\
14.88 \pm 2.55 \\
15.01 \pm 2.81 \\
14.79 \pm 2.70\end{array}$ \\
\hline Total & $(20-100)$ & $(32-100)$ & $75.19 \pm 10.82$ \\
\hline -laissez faire leadership style & $(4-20)$ & $6-20$ & $15.73 \pm 3.05$ \\
\hline
\end{tabular}


LEADERSHIP STYLES AND CONFLICT MANAGEMENT STRATEGIES etc...

Table (3): Mean scores of conflict management strategies practice as perceived by head nurses at Mansoura University Hospital .

\begin{tabular}{|c|c|c|c|c|c|c|c|}
\hline \multirow{3}{*}{$\begin{array}{c}\text { Practice of conflict } \\
\text { management strategies }\end{array}$} & \multicolumn{6}{|c|}{ Opinions of head nurses $(n=90)$} & \multirow{3}{*}{$\begin{array}{c}\text { Score } \\
\text { Range } \\
\text { Mean } \pm \text { SD }\end{array}$} \\
\hline & \multicolumn{2}{|c|}{ Low } & \multicolumn{2}{|c|}{ Moderate } & \multicolumn{2}{|c|}{ High } & \\
\hline & $\mathbf{n}$ & $\%$ & $\mathbf{N}$ & $\%$ & $\mathbf{n}$ & $\%$ & \\
\hline 1-Integrating & 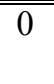 & 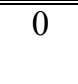 & 13 & 14.4 & 77 & 85.6 & $\begin{array}{c}17-35 \\
28.83 \pm 3.68\end{array}$ \\
\hline 2-Obliging & 0 & 0 & 24 & 26.7 & 66 & 73.3 & $\begin{array}{c}14-30 \\
23.83 \pm 2.88\end{array}$ \\
\hline 3-Compromising & 6 & 6.7 & 58 & 64.4 & 26 & 28.9 & $\begin{array}{c}4-15 \\
11.55 \pm 2.17\end{array}$ \\
\hline 4-Dominating & 13 & 14.4 & 21 & 23.3 & 56 & 62.2 & $\begin{array}{c}6-25 \\
17.72 \pm 5.29\end{array}$ \\
\hline 5-Avoiding & 19 & 21.1 & 49 & 54.4 & 22 & 24.4 & $\begin{array}{c}6-30 \\
18.13 \pm 5.57\end{array}$ \\
\hline
\end{tabular}

*Significant $(\mathbf{P}<0.05)$

Table (4): Relation between practice of transactional leadership style and conflict management strategies as perceived by head nurses at Mansoura university hospital $(\mathrm{n}=90)$.

\begin{tabular}{|c|c|c|c|c|c|c|c|c|c|}
\hline \multirow{3}{*}{\multicolumn{2}{|c|}{$\begin{array}{c}\text { Practice of conflict } \\
\text { management strategies }\end{array}$}} & \multicolumn{6}{|c|}{$\begin{array}{c}\text { Practice of transactional } \\
\text { leadership style }\end{array}$} & \multirow{3}{*}{$\chi^{2}$} & \multirow{3}{*}{$\mathbf{P}$} \\
\hline & & \multicolumn{2}{|c|}{$\begin{array}{c}\text { Low } \\
(n=1)\end{array}$} & \multicolumn{2}{|c|}{$\begin{array}{c}\text { Moderate } \\
(n=43)\end{array}$} & \multicolumn{2}{|c|}{$\begin{array}{c}\text { High } \\
(n=46)\end{array}$} & & \\
\hline & & $\mathbf{n}$ & $\%$ & $\mathbf{N}$ & $\%$ & n & $\%$ & & \\
\hline \multirow[t]{2}{*}{-Integrating } & Moderate & 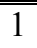 & 100 & 10 & 23.3 & 2 & 4.3 & 12.419 & $0.002^{*}$ \\
\hline & High & 0 & 0 & 33 & 76.7 & 44 & 95.7 & & \\
\hline \multirow[t]{2}{*}{-Obliging } & Moderate & 0 & 0 & 16 & 37.2 & 8 & 17.4 & 4.831 & 0.089 \\
\hline & High & 1 & 100 & 27 & 62.8 & 38 & 82.6 & & \\
\hline \multirow{3}{*}{$\begin{array}{l}\text {-Compromisi } \\
\text { ng }\end{array}$} & Low & 0 & 0 & 4 & 9.3 & 2 & 4.3 & 3.775 & 0.437 \\
\hline & Moderate & 1 & 100 & 30 & 69.8 & 27 & 58.7 & & \\
\hline & High & 0 & 0 & 9 & 20.9 & 17 & 37.0 & & \\
\hline \multirow[t]{3}{*}{-Dominating } & Low & 0 & 0 & 6 & 14.0 & 7 & 15.2 & 4.426 & 0.351 \\
\hline & Moderate & 0 & 0 & 14 & 32.6 & 7 & 15.2 & & \\
\hline & High & 1 & 100 & 23 & 53.5 & 32 & 69.6 & & \\
\hline \multirow[t]{3}{*}{-Avoiding } & Low & 0 & 0 & 8 & 18.6 & 11 & 23.9 & 1.486 & 0.829 \\
\hline & Moderate & 1 & 100 & 25 & 58.1 & 23 & 50.0 & & \\
\hline & High & 0 & 0 & 10 & 23.3 & 12 & 26.1 & & \\
\hline
\end{tabular}

*Significant $(\mathbf{P}<\mathbf{0 . 0 5})$ 
Amira A Ibrahim et. al.

Table (5): Relation between practice of transformational leadership style and conflict management strategies as perceived by head nurses at Mansoura university hospital $(n=90)$.

\begin{tabular}{|c|c|c|c|c|c|c|c|}
\hline \multirow{3}{*}{\multicolumn{2}{|c|}{$\begin{array}{c}\text { Practice of conflict } \\
\text { management strategies }\end{array}$}} & \multicolumn{4}{|c|}{$\begin{array}{c}\text { Practice of transformational } \\
\text { leadership styles }\end{array}$} & \multirow{3}{*}{$\chi^{2}$} & \multirow{3}{*}{$\mathbf{P}$} \\
\hline & & \multicolumn{2}{|c|}{$\begin{array}{c}\text { Moderate } \\
(n=34)\end{array}$} & \multicolumn{2}{|c|}{$\begin{array}{c}\text { High } \\
(\mathrm{n}=56)\end{array}$} & & \\
\hline & & $\mathbf{N}$ & $\%$ & n & $\%$ & & \\
\hline -Integrating & $\begin{array}{l}\text { Moderate } \\
\text { High }\end{array}$ & $\begin{array}{l}10 \\
24\end{array}$ & $\begin{array}{l}29.4 \\
70.6\end{array}$ & $\begin{array}{c}3 \\
53\end{array}$ & $\begin{array}{c}5.4 \\
94.6\end{array}$ & 9.905 & $0.002 *$ \\
\hline -Obliging & $\begin{array}{l}\text { Moderate } \\
\text { High }\end{array}$ & $\begin{array}{l}16 \\
18\end{array}$ & $\begin{array}{l}47.1 \\
52.9\end{array}$ & $\begin{array}{c}8 \\
48\end{array}$ & $\begin{array}{l}14.3 \\
85.7\end{array}$ & 11.620 & $0.001 *$ \\
\hline -Compromising & $\begin{array}{l}\text { Low } \\
\text { Moderate } \\
\text { High }\end{array}$ & $\begin{array}{c}3 \\
26 \\
5\end{array}$ & $\begin{array}{c}8.8 \\
76.5 \\
14.7\end{array}$ & $\begin{array}{c}3 \\
32 \\
21\end{array}$ & $\begin{array}{c}5.4 \\
57.1 \\
37.5\end{array}$ & 5.412 & 0.067 \\
\hline -Dominating & $\begin{array}{l}\text { Low } \\
\text { Moderate } \\
\text { High }\end{array}$ & $\begin{array}{c}4 \\
11 \\
19\end{array}$ & $\begin{array}{l}11.8 \\
32.4 \\
55.9\end{array}$ & $\begin{array}{c}9 \\
10 \\
37\end{array}$ & $\begin{array}{l}16.1 \\
17.9 \\
66.1\end{array}$ & 2.530 & 0.282 \\
\hline -Avoiding & $\begin{array}{l}\text { Low } \\
\text { Moderate } \\
\text { High }\end{array}$ & $\begin{array}{c}7 \\
23 \\
4\end{array}$ & $\begin{array}{l}20.6 \\
67.6 \\
11.8\end{array}$ & $\begin{array}{l}12 \\
26 \\
18\end{array}$ & $\begin{array}{l}21.4 \\
46.4 \\
32.1\end{array}$ & 5.350 & 0.069 \\
\hline
\end{tabular}

Table (6): Relationship between practices of laissez faire leadership styles and conflict management strategies as perceived by head nurses at Mansoura university hospital $(n=90)$.

\begin{tabular}{|c|c|c|c|c|c|c|c|c|c|}
\hline \multirow{3}{*}{\multicolumn{2}{|c|}{$\begin{array}{l}\text { Practices of conflict } \\
\text { management strategies }\end{array}$}} & \multicolumn{6}{|c|}{$\begin{array}{l}\text { Practices of laissez faire leadership } \\
\text { styles of the head nurses }\end{array}$} & \multirow{3}{*}{$\chi^{2}$} & \multirow{3}{*}{$\mathbf{P}$} \\
\hline & & \multicolumn{2}{|c|}{$\begin{array}{c}\text { Low } \\
(n=3)\end{array}$} & \multicolumn{2}{|c|}{$\begin{array}{c}\text { Moderate } \\
(n=36)\end{array}$} & \multicolumn{2}{|c|}{$\begin{array}{c}\text { High } \\
(n=51)\end{array}$} & & \\
\hline & & $\mathbf{n}$ & $\%$ & $\mathbf{n}$ & $\%$ & $\mathbf{n}$ & $\%$ & & \\
\hline -Integrating & $\begin{array}{l}\text { Moderate } \\
\text { High }\end{array}$ & $\begin{array}{l}2 \\
1\end{array}$ & $\begin{array}{l}66.7 \\
33.3\end{array}$ & $\begin{array}{c}9 \\
27\end{array}$ & $\begin{array}{l}25.0 \\
75.0\end{array}$ & $\begin{array}{c}2 \\
49\end{array}$ & $\begin{array}{c}3.9 \\
96.1\end{array}$ & 14.436 & "0.001* \\
\hline -Obliging & $\begin{array}{l}\text { Moderate } \\
\text { High }\end{array}$ & $\begin{array}{l}0 \\
3\end{array}$ & $\begin{array}{c}0 \\
100\end{array}$ & $\begin{array}{l}17 \\
19\end{array}$ & $\begin{array}{l}47.2 \\
52.8\end{array}$ & $\begin{array}{c}7 \\
44\end{array}$ & $\begin{array}{l}13.7 \\
86.3\end{array}$ & 13.237 & $0.001 *$ \\
\hline -Compromising & $\begin{array}{l}\text { Low } \\
\text { Moderate } \\
\text { High }\end{array}$ & $\begin{array}{l}1 \\
2 \\
0\end{array}$ & $\begin{array}{c}33.3 \\
66.7 \\
0\end{array}$ & $\begin{array}{c}2 \\
25 \\
9\end{array}$ & $\begin{array}{l}5.6 \\
69.4 \\
25.0\end{array}$ & $\begin{array}{c}3 \\
31 \\
17\end{array}$ & $\begin{array}{l}5.9 \\
60.8 \\
33.3\end{array}$ & 4.966 & 0.291 \\
\hline -Dominating & $\begin{array}{l}\text { Low } \\
\text { Moderate } \\
\text { High }\end{array}$ & $\begin{array}{l}0 \\
0 \\
3\end{array}$ & $\begin{array}{c}0 \\
0 \\
100\end{array}$ & $\begin{array}{c}3 \\
12 \\
21\end{array}$ & $\begin{array}{c}8.3 \\
33.3 \\
58.3\end{array}$ & $\begin{array}{c}10 \\
9 \\
32\end{array}$ & $\begin{array}{l}19.6 \\
17.6 \\
62.7\end{array}$ & 6.033 & 0.197 \\
\hline -Avoiding & $\begin{array}{l}\text { Low } \\
\text { Moderate } \\
\text { High }\end{array}$ & $\begin{array}{l}0 \\
3 \\
0\end{array}$ & $\begin{array}{c}0 \\
100 \\
0\end{array}$ & $\begin{array}{c}5 \\
27 \\
4\end{array}$ & $\begin{array}{l}13.9 \\
75.0 \\
11.1\end{array}$ & $\begin{array}{l}14 \\
19 \\
18\end{array}$ & $\begin{array}{l}27.5 \\
37.3 \\
35.3\end{array}$ & 15.007 & $0.005^{*}$ \\
\hline
\end{tabular}

*Significant $(\mathbf{P}<\mathbf{0 . 0 5})$ 
LEADERSHIP STYLES AND CONFLICT MANAGEMENT STRATEGIES etc...

Table (7): Correlation between leadership styles and their practice of conflict management strategies as perceived by head nurses at Mansoura university hospital.

\begin{tabular}{|c|c|c|c|c|c|c|}
\hline \multirow{3}{*}{$\begin{array}{c}\text { Practice of conflict } \\
\text { management strategies }\end{array}$} & \multicolumn{6}{|c|}{$\begin{array}{l}\text { Opinion scores of the head nurses about leadership } \\
\text { styles }(\mathbf{n}=90)\end{array}$} \\
\hline & \multicolumn{2}{|c|}{$\begin{array}{c}\text { Transactional } \\
\text { leadership } \\
\text { Styles }\end{array}$} & \multicolumn{2}{|c|}{$\begin{array}{c}\text { Transformationa } \\
\text { I leadership } \\
\text { styles }\end{array}$} & \multicolumn{2}{|c|}{$\begin{array}{c}\text { laissez faire } \\
\text { leadership } \\
\text { styles }\end{array}$} \\
\hline & $\mathbf{R}$ & $\mathbf{P}$ & $\mathbf{r}$ & $\mathbf{P}$ & $\mathbf{R}$ & $\mathbf{P}$ \\
\hline -Integrating strategies & 0.568 & "0.0001* & 0.460 & $0.0001^{*}$ & 0.493 & $0.0001^{*}$ \\
\hline -Obliging strategies & 0.366 & $0.0001 *$ & 0.390 & $0.0001^{*}$ & 0.380 & $0.0001^{*}$ \\
\hline -Compromising strategies & 0.297 & $0.004 *$ & 0.299 & $0.004 *$ & 0.420 & $0.0001^{*}$ \\
\hline -Dominating strategies & 0.083 & 0.437 & 0.032 & 0.768 & 0.093 & 0.383 \\
\hline -Avoiding strategies & 0.196 & 0.064 & 0.141 & 0.184 & 0.160 & 0.131 \\
\hline
\end{tabular}

\section{Discussion:}

Today's hospitals confronted with an increasingly competitive global health care climate, which they need to change the way they do health services in order to survive. These changes falls to their leaders to develop a variety of mechanisms and structures that contributes to improve performance, apply effective conflict management strategies and promote quality of care ${ }^{(13) .}$

Accordingly table ${ }^{(7)}$, the result shows statistically significant correlation between integrating, obliging and compromising conflict strategies practice with the three leadership styles ( transformational, transactional, laissez-faire). This is because of the effective leadership styles enhance the ability of staff nurses to perform their tasks in a higher proficiency level without the feel of stress or pressure and cooperative conflict management strategies (integrating, obliging, and compromising) leads to positive outcomes and high performance. Wade et al, found that establishing effective leadership model in any institution that promote the integrity of professionals and reduce the risk for turnover (14). Furthermore, the leadership and conflict-handling styles serve as tools to understanding the ways staff nurses promote constructive conflict management ${ }^{(15)}$.

Analysis of data revealed that, transformational leadership style achieved the highest mean score followed by laissez faire and transactional leadership. In table (5) there is statistically significances relationship between integrating, obliging practice and practice of transformational leadership style. The result may be due to that transformational leaders are sensitive to staff nurses who are more accurate at understanding and recognizing individual subordinates' needs, propose innovative methods to complete tasks and they have the priority to achieve everyone's interest than personal interest. This result is consistent with the finding of Humphreys \& Zettel reported that leaders who described themselves as more transformational used integrative conflict management styles because of their close relationship with followers should be more effective than other leaders ,these relationships should enhance followers $\square$ 
well-being and work performance

${ }^{(16)}$ Contradictory with, Lehnen et al. in Florida, found that male transformational leaders described themselves as using more of a compromising style of conflict management ${ }^{(17) \text {. }}$

The results represent that statistically significances relation between integrating, obliging and avoiding practice and practice of laissez faire leadership style in table (6). This result may be due to that laissez faire leader forms a stronger interpersonal relationships that could inherently smoothen the process of integrating ideas openly and constructively or the followers have skills and knowledge that enable them work without direction. In this respect, Ayoko \& Perkerti ${ }^{(18)}$ who reported that laissez-faire leadership showed a significant, positive correlation with the avoiding style due to incapacities in dealing with interpersonal tension, resulting in increased negative affect and the persistence of unfulfilled needs.

Contradictory, Kotlyar Karakowsky $^{(19)}$ found a significant negative relationship found between laissez-faire leadership and the integrating style, demonstrating that laissez-faire leadership is unlikely promote constructive collaborations between conflicting parties.

The findings of the present study showed that contingent reward as an item of transactional leadership had the highest mean score and most of them always perceived and practiced it which head nurses always identify nurse's needs, clarify tasks, rewards their nurses for their effort and explain to nurses how to deal with problems to meet organizational objectives. In the line with result, Obiwuru et al. they concluded that contingent reward improve the degree which leader determine rewards in exchange with followers' efforts to satisfy organizational goals ${ }^{(20)}$.

Most of head nurses in this study perceived and practiced idealized influence as an item of transformational leadership that achieved the highest score .Head nurses have a sense of self confidence and highly trusted as they deal with top management levels as they act as a role model, having strong sense of purpose and consider the moral and ethics of decisions. In this respect Dormeyer concluded that idealized influence has positively related to performance and satisfaction ${ }^{(21)}$.

In table (3): the result shows that integrating strategy has the highly degree of opinion scores followed by obliging and dominating. While avoiding strategy has the lowest degree of opinion scores. This finding is agreed with Fakhry found the integrating strategy was perceived as the most appropriate and effective strategy because it focuses on both the other and the self and the avoiding style was least effective while the dominating style was somewhat effective but not necessarily appropriate ${ }^{(22)}$. Contrast with, Barki \& Hartwick who found that staff nurses working in teams with high levels of conflict were more likely to manage conflict through domination or avoidance rather than integrating ${ }^{(23) \text {. }}$

In table (4) the study revealed that statistically significances relation between integrating strategy and practice of transactional leadership style. Head nurses focus on having internal actors perform the tasks required for the organization to reach its desired goals, remove potential barrier within the system, and to motivate the staff nurses to achieve the predetermined goals. They tend to prefer strategy that will maintain relationships in the long run. The result consistent with Hendel et al ., found that transactional leadership was found to have significant influence on the integrating strategy by creating a WinWin solution for all involved parties by openly and freely discussing the issues (4). On the other hand Alvolio \& Bass and Spinelli who made a study for assessing 
LEADERSHIP STYLES AND CONFLICT MANAGEMENT STRATEGIES etc...

transformational and transactional leadership. They found that combination of transactional and transformational leadership styles resulted in the most effective outcomes $(24,25)$.

\section{Conclusion:}

The findings of the present study concluded that, there was a highly statistical significant relation between all leadership styles and cooperative conflict management strategies (integrating, obliging and compromising) of the studied sample head nurses. Also, cooperative conflict management strategies enhance extra effort, work effectiveness and satisfaction of head nurses. Transformational leadership was the dominant practiced style followed by laissez faire and transactional leadership. As well, the integrating strategy had the highly degree of practice followed by obliging. Most of conflict arise among all members in hospital was dysfunctional. Miscommunication is the main reason of conflict on hospital followed by misunderstanding.

\section{Recommendations:}

Based on the results of this study, it was recommended that, encourage open discussion and effective communication. Designing and implementing educational program on conflict management strategies and leadership styles to manage work related conflict. Use rewards and punishments to keep staff nurses on the path toward achieving hospital goals. Watch for deviations from rules and standards and taking corrective action to prevent mistakes to increase management by exception active. Good understanding of the strengths and weaknesses of the nursing team members in order to improve relations and manage conflict successfully. Promote critical thinking

and the scientific method to solve problems by providing opportunities for staff nurses to express their opinion and participation in the development of new ideas and non-traditional solutions to improve performance.

\section{References:}

1- Riaz A., and Haider M., (2010): Role of transformational and transactional leadership on job satisfaction and career satisfaction. Business and Economic Horizons; 1(1): 29-38.

2- Fan C.W., (2004): Transformation and Transactional Leadership of Elementary School Masters and Organizational Performances of Schools", Taiwan, Journal of National Hualien Teachers College;19(1): 21-40

3- Cornelius J. I ., (2013): Leadership Styles For Dealing With People, Part 2: Putting Effective Leader Styles to Work for You .Collegiate Project Services

http://www.collegiateproject.com

[Retrieved October $\left.2^{\text {nd }}, 2014\right]$

4- Hendel T., Fish M., and Galon V., (2005): Leadership style and choice of strategy in conflict management among Israeli nurse managers in general hospitals. Journal of Nursing Management, 13(2), 137-146.

5- Wang G., (2011):Transformational leadership and performance across criteria and levels: a meta-analytic review of 25 years of research. Group and Organization Management; 36(2): 233-270.

6- Nouman M., (2011): Conflicts and strategies for their resolution: A case of organizations. Interdisciplinary Journal of Contemporary Research in Business. Institute of Interdisciplinary Business Research, Pakistan; 3 (5):620.

7- Rahim MA., (2001): Managing Conflict in Organizations. 3rd ed. British Library, Printed in the United States of America, $\mathrm{p}_{\mathrm{p}} 33$. 
8- Sportsman S., and Hamilton P., (2007): Conflict management styles in the health professions. Journal of Professional Nursing; 23 (3): 157-166.

9- Wilmot W.W., and Hocker J., (2011): Interpersonal conflict (8th ed.). New York: cGraw-Hill.p11

10-Bass B. M., and Avolio B. J., (1995): MLQ Multifactor Leadership Questionnaire for research: permission set. Redwood City, CA: Mindgarden..

11-Rahim A., (2010): Functional and dysfunctional strategies for managing conflict. In: Massachusetts, 23rd Annual International association of conflict management conference. Boston, USA, 24-27 June 2010.

12-Rahim, A.M., (1983): A measure of styles of handling interpersonal conflict. Academy of Management Journal;26(2): 368-376.

13-Slabbert A., (2004): Conflict management styles in traditional organisations. Social Science Journal Colorado Then New York-Western Social Science Association; 41(1): 8392.

14- Wade G.H., Osgood B., and Avino K., (2008): Influence of organizational characteristics and caring attributes of managers on nurses' job enjoyment. Journal of Advanced, 64(4), 344-53.

15- Cerni T., Curtis G.J., and Colmar S.H., (2012): Cognitive-experiential self theory and conflict-handling styles: rational and constructive experiential systems are related to the integrating and compromising conflict-handling styles. International Journal of Conflict Management; 23(4): 362-381.

16- Humphreys J.H., and Zettel, M.C., (2002): Transformational leader selfperceptionand objective sales performance: The potential moderating effects of behavioral coping ability. International Business \& Economics Research Journal; 1(1): 9-23.

17- Lehnen P.L., Ayman R., and Korabik K., (1995): Transformational leadership, conflict management styles and subordinates' satisfaction with supervision. Paper presented at the tenth annual conference of the Society of Industrial and Organizational Psychology, Orlando, Florida.

18-Ayoko O.B., and Pekerti A., (2008): The mediating and moderating effects of conflict and communication openness on workplace trust. International Journal of Conflict Management; 19 (4): 297-318.

19-Kotlyar I., and Karakowsky L., (2007): Leading Conflict? Linkages Between Leader Behaviors and Group Conflict Small Group Research; 37(4): 377-403.

20-Obiwuru T.C. , Okwu A.T., Akpa V.O., and Nwankwere I .A., (2011): Effects of Leadership on Organizational Performance : A Survey of Selected Small Scale Enterprises in Ikosi-Ketu Council Development Area of Lagos State. Babcock University, Nigeria. Australian Journal of Business and Management Research;1 (7): 100-111.

21-Dormeyer S., (2003): A study about the Leadership and the Organizational Climate at the Swedish civil Air Aviation Administration. Malmosturup. Lund University [phD thesis]. Available from: http//lup.lub.lu.se/luur. [Retrived 3/10/2014].

22- Fakhry F.S., and Abou El Hassan A. N., (2011): Causes and Types of Conflict and Resolution Strategies among Nursing Students: A Comparative Study between Two Cultures. Faculty of Nursing. Ain 
LEADERSHIP STYLES AND CONFLICT MANAGEMENT STRATEGIES etc...

Shams University, Egypt \& Beirut Arab University, Lebanon .Journal of American Science; 7(4): 227-230.

23- Barki H., and Hartwick J., (2001): Interpersonal conflict and its management in information systems development. MIS Quarterly; 25(2):217- 250 .

24- Alvolio B.J., Bass B.M., (2003): Predicting Unit Performance by Assessing Transformational and
Transactional Leadership. Journal of Applied Psychology; 88(2):207-18.

25- Spinelli R.J., (2006): Applicability of Bass's Model of Transformational, Transactional and laissez faire Leadership in the Hospital Administrative Environment. Hospital Topics; 84(2): 11-8. 